\title{
Originals
}

\section{Coronary heart disease in young Type 1 (insulin-dependent) diabetic patients with and without diabetic nephropathy: incidence and risk factors}

\author{
T.Jensen, K. Borch-Johnsen, A. Kofoed-Enevoldsen and T. Deckert \\ Steno Memorial Hospital, Genotofte, Denmark
}

\begin{abstract}
Summary. Fifty-nine Type 1 (insulin-dependent) diabetic patients with (group I) and 59 patients without nephropathy (group II) pair-matched according to sex ( 30 males and $29 \mathrm{fe}-$ males), age (33 years, range 15-48) and diabetes duration (19 years, range 6-42) were followed for a period of 10 years from about 5 years before to 5 years after onset of proteinuria. The cumulative incidence of coronary heart disease was estimated, and blood pressure and serum cholesterol were followed. Within six years after onset of proteinuria the cumulative incidence of coronary heart disease was increased eight-fold in group I (40\%) compared with group II (5\%), $(p<0.001)$. Blood pressure was higher in group I compared with group II from before onset of proteinuria (135/86 \pm $17 / 9 \mathrm{mmHg}$ vs $129 / 80 \pm 15 / 8 \mathrm{mmHg}, p<0.001$ ), and serum cholesterol elevated from onset of proteinuria in group I $(6.3 \pm 1.2 \mathrm{mmol} / \mathrm{l})$ vs. group II $(5.5 \pm 1.0 \mathrm{mmol} / 1),(p<0.005)$. Patients in group $I$ who developed coronary heart disease had similar age (36 years, range $21-51$, vs 38 years, range $21-53$ ),
\end{abstract}

sex (50\% males vs. $52 \%$ males), smoking frequency ( $50 \%$ vs $49 \%$ ), diabetes duration (22 years, range $9-39$, vs 24 years, range $10-42)$ and serum creatinine $(110 \mu \mathrm{mol} / 1$, range $69-284$, vs $108 \mu \mathrm{mol}$, range $72-1024)$ compared with patients not developing coronary heart disease. However, the patients with coronary heart disease had higher blood pressure $(135 / 87 \mathrm{mmHg} \pm 16 / 9$ vs $128 / 82 \pm 15 / 7, p<0.05)$ and serum cholesterol $(7.3 \mathrm{mmol} / 1+1.2$ vs $6.4 \mathrm{mmol} / 1 \pm 0.9, p<0.05)$ than patients without coronary heart disease. Thus, patients developing clinical nephropathy have a highly increased incidence of coronary heart disease compared with patients not developing nephropathy. Patients who developed coronary heart disease were characterized by higher blood pressure and serum cholesterol.

Key words: Type 1 (insulin-dependent) diabetes, diabetic nephropathy, coronary heart disease, cardiovascular risk factors.
Congestive heart failure and ischaemic heart disease are major complications of diabetes mellitus [1, 2]. Recent studies have shown that increased urinary protein excretion in Type 1 (insulin-dependent) [3] as well as in Type 2 (non-insulin-dependent) $[4,5]$ diabetic patients is a predictor of cardiovascular death. Angiographic studies of diabetic patients with chronic renal failure have shown severe and widespread occlusive atherosclerosis of the coronary arteries [6], and impaired left ventricular function has been found in young diabetic patients with retinopathy and nephropathy $[7,8]$. The cause of this increased frequency of cardiovascular disease among patients with clinical nephropathy remains unknown. However, insulin-dependent diabetic patients with nephropathy have elevated blood pressure $[9$, 10], higher smoking frequency [11], increased transcapillary escape rate of albumin [12], increased plasma fibrinogen and increased total cholesterol [13] when compared with patients without clinical nephropathy. The purpose of our study was to investigate the incidence of coronary heart disease (CHD) and its associations to blood pressure, serum cholesterol and smoking in a cohort of young insulin-dependent diabetic patients during early clinical nephropathy.

\section{Subjects and methods}

All patients with Type 1 diabetes mellitus (onset before age 31 years) and current age between 18 and 50 years, who during their follow-up 1975-81 at the Steno Memorial Hospital developed clinical nephropathy, were included in the study (group I, $n=59$ ). Clinical nephropathy was defined as (1) urinary protein excretion exceeding $0.5 \mathrm{~g} /$ day at four consecutive visits to the outpatient clinic, and (2) no clinical or laboratory evidence of renal tract infection or kidney disease other than glomerulosclerosis. From our records of patients known not to have developed diabetic nephropathy, 4-10 subjects matched according to sex, age ( \pm 5 years) and diabetes duration ( \pm 5 years) were identified for each patient (total 278 subjects). Of these, 59 control subjects were selected randomly (group II). All patients were seen in 
Table 1. Clinical features of the patients studied

\begin{tabular}{|c|c|c|c|c|c|c|c|c|}
\hline & $\begin{array}{l}\text { Number of } \\
\text { patients }\end{array}$ & $\begin{array}{l}\operatorname{Sex} \\
(\mathrm{M} / \mathrm{F})\end{array}$ & $\begin{array}{l}\text { Age } \\
\text { (years) }\end{array}$ & $\begin{array}{l}\text { Diabetes } \\
\text { duration } \\
\text { (years) }\end{array}$ & $\begin{array}{l}\text { Age at onset } \\
\text { of diabetes } \\
\text { (years) }\end{array}$ & $\begin{array}{l}\text { Serum } \\
\text { creatinine } \\
\mu \mathrm{mol} / 1\end{array}$ & $\begin{array}{l}\text { Eye back- } \\
\text { ground }\end{array}$ & \\
\hline $\begin{array}{l}\text { Patients with persistent } \\
\text { proteinuria }\end{array}$ & 59 & $30 / 29$ & $33(18-46)$ & $19(6-39)$ & $14(1-28)$ & $86(72-133)$ & $\begin{array}{l}\text { Normal } \\
\text { Simplex } \\
\text { Proliferative }\end{array}$ & $\begin{array}{r}5 \\
25 \\
29\end{array}$ \\
\hline \multirow[t]{2}{*}{$\begin{array}{l}\text { Patients without } \\
\text { proteinuria }\end{array}$} & 59 & $30 / 29$ & $33(15-48)$ & $19(6-42)$ & $13(2-28)$ & $78(57-106)$ & $\begin{array}{l}\text { Normal } \\
\text { Simplex } \\
\text { Proliferatives }\end{array}$ & $\begin{array}{r}41 \\
12 \\
6\end{array}$ \\
\hline & & & $N^{a}{ }^{a}$ & $\mathrm{NS}^{\mathrm{a}}$ & $\mathrm{NS}^{\mathrm{a}}$ & $p<0.01^{\mathrm{a}}$ & $p<0.001^{\mathrm{b}}$ & \\
\hline
\end{tabular}

Results given as median and range. ${ }^{\mathrm{a}}$ Mann-Whitney test; ${ }^{\mathrm{b}} \mathrm{Chi}$-squared test

Table 2. Distribution of coronary heart disease

\begin{tabular}{lll}
\hline & $\begin{array}{l}\text { Patients } \\
\text { with persistent } \\
\text { proteinuria } \\
\text { (group I) }\end{array}$ & $\begin{array}{l}\text { Patients } \\
\text { without } \\
\text { proteinuria } \\
\text { (group II) }\end{array}$ \\
\hline Myocardial infarction & & \\
Acute (WHO criteria) & 4 & 0 \\
Fatal (autopsy verified) & 3 & 0 \\
Silent (Minnesota code 1.1-2) & 4 & 1 \\
Myocardial ischaemia (ECG-changes) & \\
Minnesota-code 1.3 & $4(2)^{\mathrm{a}}$ & $4(0)^{\mathrm{a}}$ \\
Minnesota-code 4.1-4 & $4(3)^{\mathrm{a}}$ & 0 \\
Minnesota-code 5.1-3 & $3(1)^{\mathrm{a}}$ & $1(0)^{\mathrm{a}}$ \\
Minnesota-code 7.1 & 0 & 0 \\
\hline & $22 / 59$ & $6 / 59$ \\
& & $p<0.001^{\mathrm{b}}$ \\
\hline
\end{tabular}

${ }^{a}$ Patients with accompanying angina pectoris; ${ }^{b}$ chi-squared test

the outpatient clinic every third month. In the period 1972 to 1985 the following clinical and laboratory parameters were registered:

1. 9-lead (I, II, III, $\mathrm{V}_{1-6}$ ) resting ECG (mean interval 3 years). The records were coded independently in duplicate by trained and tested technicians using the Minnesota-code [14].

2. Clinical coronary heart disease. Autopsy verified myocardial infarction or non-fatal myocardial infarction according to the WHO criteria [15]. Angina pectoris defined in accordance with Rose [16]. Patients were defined to have coronary heart disease (CHD) when: resting ECG showed signs of probable myocardial infarction (Minnesotacode 1.1-2) or possible myocardial ischaemia (Minnesota-code 1.3, $4.1-4,5.1-3$ or 7.1 ), or when clinical coronary heart disease as defined above was present.

3. Blood pressure (mean interval 3 years) with a standard clinical sphygmomanometer (cuff $25 \times 12 \mathrm{~cm}$ ) with the subject in the supine position for at least $10 \mathrm{~min}$. Diastolic blood pressure was measured at disappearance of of the Korotkoff sounds (phase 5). From all blood pressure measurements mean systolic and diastolic blood pressure were calculated in the periods before, at and after onset of proteinuria for each patient.

4. Serum cholesterol (mean interval 2 years) was determined according to Abell [17]. From all values mean serum cholesterol was calculated in the periods before, at and after onset of proteinuria for each patient.

5. Serum creatinine was measured by a reaction rate method eliminating pseudocreatinines [18].

The eye background was examined by opthalmoscopy through the dilated pupil and classified as normal, simplex or proliferative retinopathy.
Proteinuria was tested at each outpatient visit (every third month) with Albustix (Boehringer, Mannheim, FRG). If the qualitative reaction was positive a quantitative examination was performed by Tsuchiya's method [19].

Smokers were defined as those smoking more than one cigarette per day, all others being classified as non-smokers.

\section{Statistical analysis}

Results are given as mean \pm SD and median and range when values were normal or not normally distributed respectively. Paired and unpaired Student's t-tests were used for comparison within and between groups. The Mann-Whitney test was used for comparison between groups when values were not normally distributed. For evaluating frequencies the chi-squared test was used. Cumulative incidences of CHD were calculated using actuarial lifetable analysis. Levels of significance were found by Gehan's test. The risk of Type 1 error was set at $p<0.05$.

\section{Results}

The patients' clinical data at onset of proteinuria are shown in Table 1 . The perfect match of the two groups regarding sex, age and diabetes duration is demonstrated. The mean follow-up in group I was 5 years prior to and 5.1 years after onset of proteinuria. Group II was followed to the same age and diabetes duration.

All patients had initially normal ECG and no clinical symptoms of coronary heart disease. In group I two patients developed CHD before onset of proteinuria and 20 patients developed CHD after. The corresponding values in group II were 1 and 5 respectively $(p<$ 0.001 ). The characteristics of CHD in the two groups are shown in Table 2. The 59 pairs were followed for 2-9 years after onset of proteinuria, but only 9 pairs were followed for more than 6 years. Within the first 6 years after onset of proteinuria, the cumulative incidence of CHD calculated by actuarial lifetable analysis was eight times higher among patients with clinical nephropathy compared with patients without proteinuria (Fig.1). At the start of the study blood pressure was equal in group I and II $(127 / 80 \pm 15 / 7 \mathrm{mmHg}$ vs $126 / 78 \pm 16 / 8 \mathrm{mmHg}$ ). However, as shown in Figure 2, blood pressure rose in group I even in the period before onset of proteinuria $(135 / 86 \pm 17 / 9 \mathrm{mmHg}$ vs 


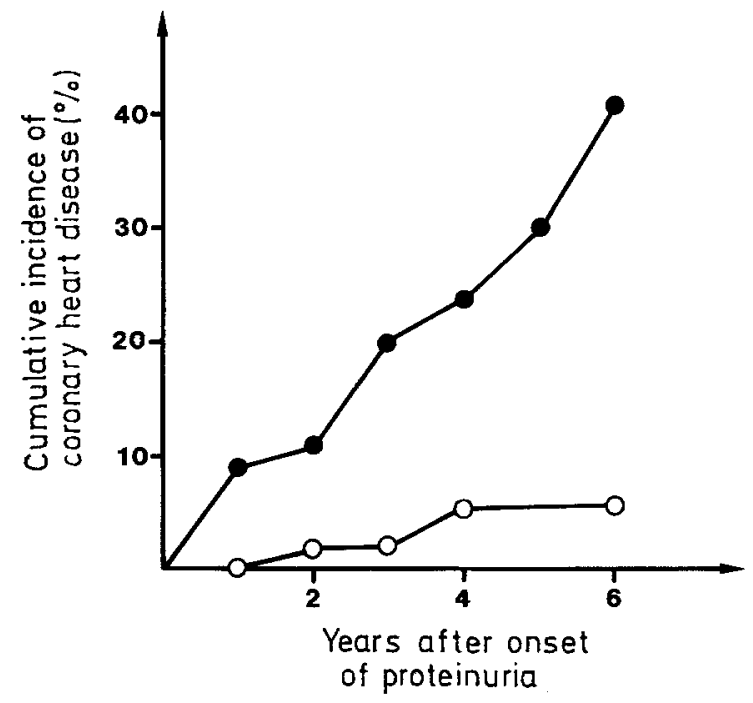

Fig.1. Cumulative incidence of coronary heart disease in patients with $(\longrightarrow)$ and without $(\mathrm{O}-\mathrm{O})$ proteinuria. Chi-square: 14.3 ; $p<0.001$

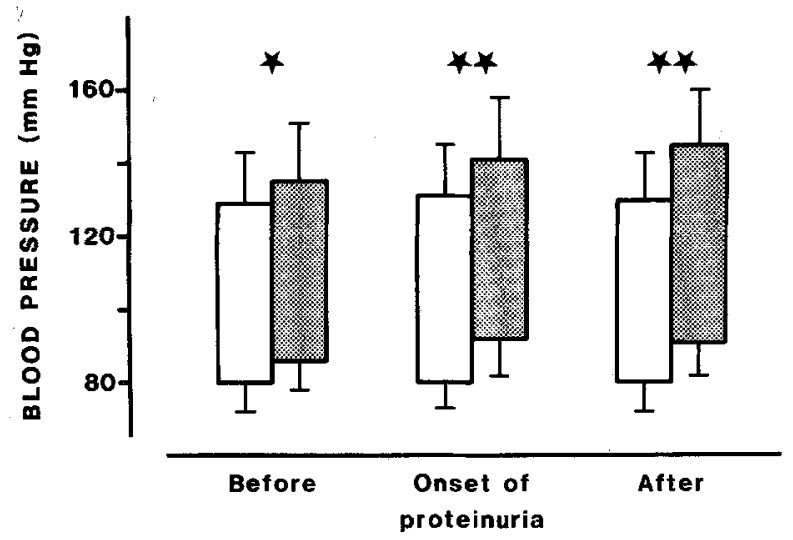

Fig. 2. Systolic and diastolic blood pressure in the periods before, at and after onset of proteinuria. Shaded columns indicate patients with persistent proteinuria. Open columns indicate patients without proteinuria. Results are expressed as mean $\pm \mathrm{SD}^{*} p<0.05^{* *} p<0.01$

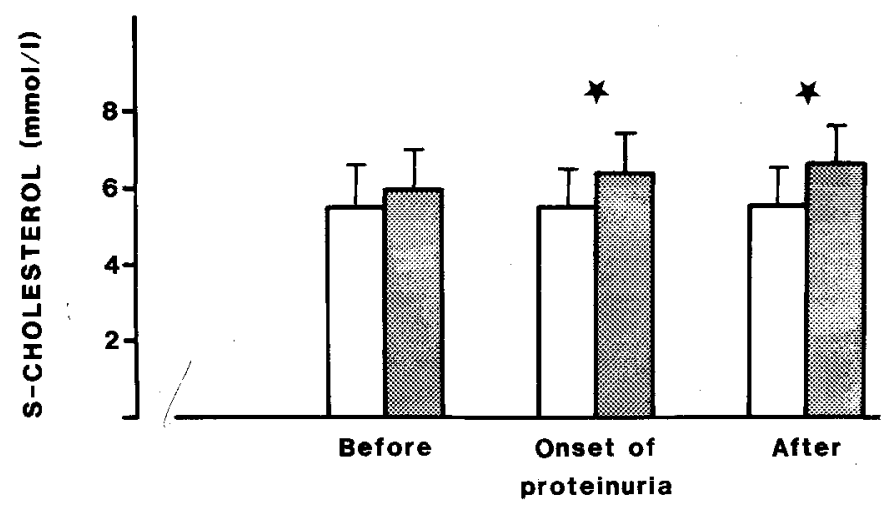

Fig. 3. Serum cholesterol in the periods before, at and after onset of proteinuria. Shaded columns indicate patients with persistent proteinuria. Open columns indicate patients not developing proteinuria. Results are expressed as mean $\pm \mathrm{SD} .{ }^{*} p<0.05$
Table 3. Clinical data on and laboratory results for proteinuric patients with or without coronary heart disease (CHD) Values given at the end of the follow-up period

\begin{tabular}{|c|c|c|c|}
\hline & With CHD & Without CHD & \\
\hline Number & 22 & 37 & \\
\hline Age (years) ${ }^{\mathrm{a}}$ & $36(21-51)$ & $38(21-53)$ & ns \\
\hline $\operatorname{Sex}(M / F)$ & $11 / 11$ & $19 / 18$ & ns \\
\hline $\begin{array}{l}\text { Diabetes duration } \\
\text { (years) }\end{array}$ & $22(9-39)$ & $24(10-42)$ & ns \\
\hline $\begin{array}{l}\text { Serum creatinine } \\
(\mu \mathrm{mol} / \mathrm{l})^{\mathrm{a}}\end{array}$ & $110(69-284)$ & $108(72-1024)$ & ns \\
\hline \multicolumn{4}{|l|}{$\begin{array}{l}\text { Serum cholesterol } \\
(\mathrm{mmol} / 1)^{\mathrm{b}}\end{array}$} \\
\hline $\begin{array}{l}\text { Before onset of } \\
\text { proteinuria }\end{array}$ & $6.3 \pm 1.2$ & $5.7 \pm 1.1$ & ns \\
\hline At onset of proteinuria & $6.8 \pm 1.0$ & $6.1 \pm 1.0$ & $p<0.05$ \\
\hline $\begin{array}{l}\text { After onset of } \\
\text { proteinuria }\end{array}$ & $7.3 \pm 1.2$ & $6.4 \pm 0.9$ & $p<0.05$ \\
\hline \multicolumn{4}{|l|}{ Blood pressure $(\mathrm{mmHg})^{\mathrm{b}}$} \\
\hline $\begin{array}{l}\text { Before onset of } \\
\text { proteinuria }\end{array}$ & $135 / 87 \pm 16 / 9$ & $128 / 82 \pm 15 / 9$ & $p<0.05$ \\
\hline At onset of proteinuria & $144 / 93 \pm 17 / 10$ & $138 / 91 \pm 15 / 10$ & ns \\
\hline $\begin{array}{l}\text { After onset of } \\
\text { proteinuria }\end{array}$ & $150 / 92 \pm 16 / 9$ & $143 / 91 \pm 16 / 11$ & ns \\
\hline Smokers & $11(50 \%)$ & $18(49 \%)$ & ns \\
\hline
\end{tabular}

Results given as a median and range (Mann-Whitney test) or ${ }^{b}$ mean $\pm S D$ (Student's t-test)

$129 / 80 \pm 15 / 8 \mathrm{mmHg}, p<0.01$ ). Hypertension (diastolic blood pressure $\geq 95 \mathrm{mmHg}$ ) was found in $25(43 \%)$ of the proteinuric patients at onset of proteinuria. In addition, 21 patients developed hypertension after onset of proteinuria and antihypertensive treatment was initiated. Only 6 patients $(10 \%)$ in group II developed hypertension after the same diabetes duration.

Serum cholesterol was similar in group I and II at the start of the study $(5.7 \pm 1.1 \mathrm{mmol} / 1$ vs $5.5 \pm$ $1.0 \mathrm{mmol} / \mathrm{l}$ ) and, as shown in Figure 3, in the period before onset of proteinuria. From onset of proteinuria

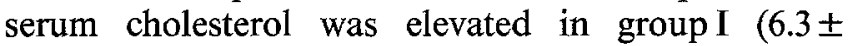
$1.2 \mathrm{mmol} / \mathrm{l})$ compared with group II $(5.5 \pm 1.0 \mathrm{mmol} / \mathrm{l}$, $p<0.05)$. The number of smokers were equal in group I $(29(49 \%))$ and group II $(33(56 \%))$.

In the group of patients developing clinical nephropathy there was no difference as to age, sex, diabetes duration, smoking frequency or serum creatinine between the patients who developed CHD and those who did not (Table 3). However, the patients with CHD had higher blood pressure and serum cholesterol compared with the patients without CHD.

\section{Discussion}

This study represents a case control within a cohort study of patients with insulin-dependent diabetes mellitus, with group I developing persistent proteinuria in the period 1975 to 1981 and group II not developing proteinuria during the follow-up period. Testing for proteinuria at each outpatient visit, and the exclusion of 
patients admitted to the Steno Memorial Hospital with persistent proteinuria, ensure the exact time of onset of proteinuria. As to the reliability of electrocardiograms, blood pressure measurements and cholesterol determinations, the conditions at examination were identical for both groups, and data from both groups were obtained during the same period.

Morphological studies have previously shown the co-existence of micro- and macrovascular abnormalities in diabetic patients. In 36 of 50 diabetic patients, Zoneraich et al. [20] found abnormalities in small intramural arteries. Half of these patients demonstrating small vessel disease also showed larger coronary artery occlusions. Using angiography Weinrauch [6] described widespread occlusive atherosclerosis of the coronary arteries in 9 of 21 asymptomatic diabetic patients with end-stage renal disease. In other studies, however, heart failure has been attributed to small vessel disease of the coronary circulation with relatively normal coronary arteries [21, 22]. Our study demonstrated an excessively high incidence of major electrocardiographic abnormalities and clinical coronary heart disease within the first years after onset of proteinuria in young diabetic patients compared with diabetic patients without proteinuria. This observation is new, and is in accordance with the increased relative mortality in patients with diabetic nephropathy shown in previous studies [3-5]. It also fits with previous findings of a huge increase of cardiovascular mortality found in patients with proteinuria $[4,5,23]$. The low annual incidence of coronary heart disease in our diabetic patients without proteinuria is in accordance with the only slightly increased relative mortality seen in patients without proteinuria $[3,23]$.

In this study the high incidence of coronary heart disease among proteinuric patients was not confined to males or smokers. On the contrary, patients with and without proteinuria were comparable as to smoking frequency and male/female ratio. Smoking did not influence the development of coronary heart disease in the proteinuric patients.

In agreement with others, our study demonstrated elevated blood pressure and serum cholesterol in diabetic patients with proteinuria compared with diabetic patients without proteinuria $[9,10,13]$. Elevated serum cholesterol has long been noted in patients with nondiabetic nephrosis [24]. Although the mechanism responsible remains unknown, much evidence supports increased hepatic lipoprotein production as the principal contribution to elevated levels of cholesterol $[25,26]$. It is widely held that elevated blood pressure [27] and serum cholesterol [28] are major contributors to coronary heart disease. In the recent Lipid Research Clinics Coronary Primary Prevention Trial among middle-aged men, a reduction in total cholesterol of only $8 \%$ resulted in a $20 \%$ decrease in cardiovascular mortality. On the other hand, it seems unlikely that the observed changes in blood pressure and serum cholesterol fully explain the huge increase in coronary heart disease among pat- ients with diabetic nephropathy. Further studies are needed to clarify the influence of haemostatic abnormalities and changes in vascular permeability, especially of lipoproteins, in these patients.

It is not known whether reduction of blood pressure and serum cholesterol in patients with diabetic nephropathy will decrease the incidence of CHD. However, the increasing evidence from preventive trials in non-diabetic populations makes controlled intervention studies focusing on the elevated blood pressure and lipid abnormalities in this high risk group of Type 1 diabetic patients highly attractive.

\section{References}

1. Kannel WB, McGee DL (1979) Diabetes and cardiovascular disease. The Framingham study. JAMA 241: 2035-8

2. Jarrett RJ, McCartney P, Keen H (1982) The Bedford Survey. Tenyear mortality rates in newly diagnosed diabetics and normoglycaemic controls and risk indices for coronary heart disease in borderline diabetics. Diabetologia 22: 79-84

3. Borch-Johnsen K, Kragh Andersen P, Deckert T (1985) The effect of proteinuria on relative mortality in Type 1 (insulin-dependent) diabetes mellitus. Diabetologia 28: 590-96

4. Mogensen CE (1984) Microalbuminuria predicts clinical proteinuria and early mortality in maturity-onset diabetes. $\mathrm{N}$ Engl $\mathrm{J}$ Med 6: $356-60$

5. Jarrett RJ, Viberti GC, Argyropoulos A, Hill RD, Mahmud U, Murrells TJ (1984) Microalbuminuria predicts mortality in noninsulin-dependent diabetes. Diabetic Med 1: 17-9

6. Weinrauch L, D'Elia JA, Healy RW, Gleason RE, Christlieb AR, Leland OS (1978) Axymptomatic coronary artery disease: angiographic assessment of diabetics evaluated for renal transplantation. Circulation 58: 1184-90

7. Seneveratne BIB (1977) Diabetic cardiomyopathy: the preclinical phase. Br Med J 1: 1444-6

8. Sanderson JE, Brown DJ, Rivellese A, Kohner E (1978) Diabetic cardiomyopathy? An echocardiographic study of young diabetics. Br Med J 1: 404-7

9. Parving HH, Andersen AR, Smidt UM, Oxenbøll B, Edsberg B, Sandahl Christiansen J (1983) Diabetic nephropathy and arterial hypertension. Diabetologia 24: 10-12

10. Feldt-Rasmussen B, Borch-Johnsen K, Mathiesen ER (1985) Hypertension in diabetes as related to nephropathy. Early blood pressure changes. Hypertension 7 [suppl II]: II-18-II-20

11. Christiansen JS (1978) Cigarette smoking and prevalence of microangiopathy in juvenile onset insulin-dependent diabetes mellitus. Diabetes Care 1: 146-49

12. Feldt-Rasmussen B (1986) Increased transcapillary escape rate of albumin in Type 1 (insulin-dependent) diabetic patients with microalbuminuria. Diabetologia $29: 282-6$

13. Valdorf-Hansen F (1967) Coagulability in diabetics. Acta Med Scand, Supplementum 476: 147-57

14. Blackburn H, Keys A, Simonsen E, Rautaharju P, Punsar S (1960) The electrocardiogram in population studies: a classification system. Circulation 21: 1160-75

15. Rose G, Blackburn H (1968) Cardiovascular survey methods. World Health Organization Monograph Series No.56, WHO, Geneva

16. Rose GA (1962) The diagnosis of ischaemic heart pain and intermittent claudication in field surveys. Bull WHO 27: 645-58

17. Abell LL, Levy BB, Biodie BB, Kendall FE (1952) A simplified method for the estimation of total cholesterol in serum and demonstration of its specificity. J Biol Chem 195:357-60

18. Larsen $K$ (1972) Creatinine assay by a reaction-kinetic principle. Clin Chim Acta 41: 209-17 
19. Tsuchiya (1908) Eine neue volumetrische Eiweissbestimmung mittels der Phosphorwolframsaure. Zenhalbl Inn Med 29: 105-15

20. Zoneraich S, Silverman G, Zoneraich O (1980) Primary myocardial disease, diabetes mellitus, and small vessel disease. Am Heart J 100: 754-5

21. Regan TJ, Lyons MM, Ahmed SS, Levinsson GE, Oldewurtel HA, Ahmad MR, Harder B (1977) Evidence for cardiomyopathy in familial diabetes mellitus. J Clin Invest 60:885-99

22. Shapiro LM, Leatherdale BA, Mackinnon J, Fletcher RF (1981) Left ventricular function in diabetes mellitus. II: Relation between clinical features and left ventricular function. Br Heart $\mathrm{J}$ 45: 129-32

23. Borch-Johnsen K, Kreiner S (1986) Proteinuria predicts high relative mortality of cardiovascular disease in Type 1 (insulin-dependent) diabetic patients. Diabetologia 029:521 A

24. Baxter JH, Goodman HC, Havel RJ (1960) Serum lipid and lipoprotein alterations in nephrosis. J Clin Invest 39: 455-65

25. Appel GB, Blum CB, Shu Chien, Kunis CL, Appel AS (1985) The hyperlipidemia of the nephrotic syndrome. Relation to plasma albumin concentration, oncotic pressure and viscosity. $\mathrm{N}$ Engl $\mathrm{J}$ Med 312: 1544-48

26. Marsh JB, Sparks CE (1979) Hepatic secretion of lipoproteins in the rat and the effect of experimental nephrosis. J Clin Invest 64: 1229-37

27. Christlieb AR (1982) The hypertensions of diabetes. Diabetes Care 5: 50-8

28. Lipid Research Clinics Program (1984) The Lipid Research Clinics Coronary Primary Prevention Trial Results. JAMA 251: 351-74

Received: 16 October 1986

and in revised form: 28 January 1987

Dr. Tonny Jensen

Steno Memorial Hospital

DK-2820 Gentofte

Denmark 